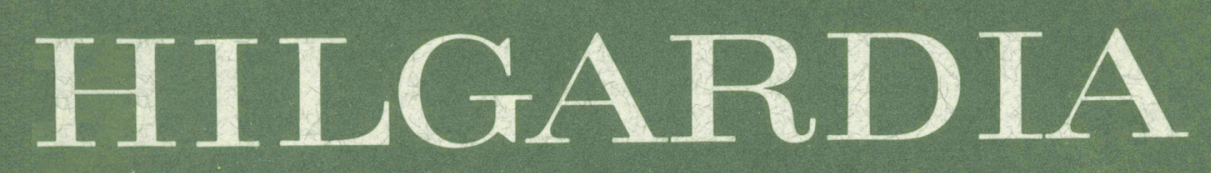

A JOURNAL OF AGRICULTURAL SCIENCE PUBLISHED BY THE CALIFORNIA AGRICULTURALEXPERIMENT STATION

Volume 47, Number $3 \bullet$ April, 1979

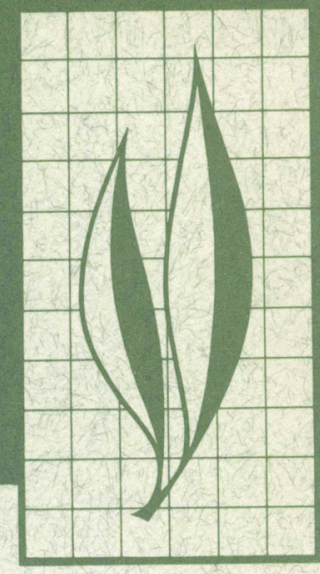

\title{
Reactions of Northern California Grass-woodland to Vegetational Type Conversions
}

H. F. Heady and M. D. Pitt 


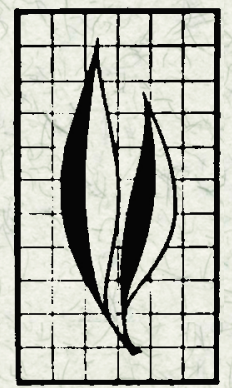

Changes in standing crop, cover, and percent botanical composition of annual vegetation as influenced by microsite and type conversion were investigated on an 86.2 hectare watershed at the Hopland Field Station, Mendocino County, California.

Type conversion from woody vegetation to grassland tripled total standing crop of herbaceous plants on the watershed, with much of this increase occurring on sites formerly supporting a dense and semidense woodland overstory. However, the sites that were originally woodland never produced as much forage as those that were originally open grassland. The managerial problem of seasonally adjusting stocking rates in response to changing forage availability was heightened by type conversion, since much of the increased forage production occurred at the end of the growing season.

Short annual plants, such as nitgrass, silver hairgrass, rattlesnake weed, filaree, bur-clover, and true clovers, attained their greatest percent botanical composition on the historically open grassland sites. Type conversion produced increases in botanical composition primarily for those taller annual and perennial plant species capable of colonizing the formerly dense woodland sites mainly occurring on north-facing slopes. These plant species included wild oats, ripgut, vetches, and Italian thistle.

In the sheep-grazing system employed, adding animal units to utilize increased spring forage following brush conversion required alternative sources of feed during other periods of the year.

THE AUTHORS:

H.F. Heady is Professor of Range Management, Department of Forestry and Resource Management; he is also Assistant Vice President of Agriculture and University Services, and Associate Director, Agricultural Experiment Station, Berkeley.

M.D. Pitt, formerly Research Assistant, Department of Forestry and Resource Management, Berkeley, is Assistant Professor of Range Ecology, Department of Plant Science, University of British Columbia, Vancouver, B.C., Canada. 


\section{Reactions of Northern California Grass-woodland to Vegetational Type Conversions ${ }^{1}$}

A TECHNIQUe COMMONLY EMPLOYeD to achieve multiple objectives on rangeland is the conversion of predominantly woody cover to predominantly grass cover. Grassy vegetation provides better forage for grazing animals and typically releases greater quantities of water than does woody vegetation. Additionally, young stands of brush and trees, interspersed with patches of grass, provide improved wildlife habitat, better fire control, and visual aesthetics (Bentley, 1967).

Before a vegetational cover-type conversion project is undertaken, its purpose and potential benefits must be carefully assessed (Bentley, 1967). This process necessarily includes the impact of the change in vegetative cover on all management objectives. Failure to evaluate these impacts effectively has produced inconsistent results and considerable controversy over the suitability of type conversion to increase forage production in California. Much of the controversy arises because the responses to type conversion have not been carefully separated from the concomitant influences of site, grazing intensity, and annual variability in forage production.

Soil capabilities are highly variable in California. Plots less than 30 meters (m) apart on Montezuma clay showed tenfold differences in relative botanical composition for individual plant species (Biswell, 1956). Other site characteristics, such as topography, also affect grassy vegetation. Bentley and Talbot (1951) classified different topographic types of rangelands as an aid in determining grazing capacity. These types, in increasing order of herbage production, were steep rocky bluffs, steep slopes, rocky brushland, rolling slopes, open rolling slopes, gentle slopes, and swales. Additionally, north exposures on rolling topography were commonly observed to be more productive than south exposures. On very steep north exposures, however, the forage often thinned, particularly when shaded by dense tree canopies. Thus, both soil and topography exert profound influences on vegetation before and after type conversion.

Weather patterns also play a significant role in determining the success of type conversion projects in California. Fluctuations in herbage productivity and relative botanical composition exceeding 100 percent from one year to the next are the direct result of both temperature and precipitation patterns (Talbot, Biswell, and Hormay, 1939; Bentley and Talbot, 1951; Heady, 1956; Heady, 1958; Naveh, 1967; McNaughton, 1968; Hooper and Heady, 1970; Murphy, 1970; Duncan and Woodmansee, 1975; Pitt and Heady, 1978). Thus, increases in forage production subsequent to type conversion may be the result more of annual weather patterns than conversion per se.

Variable utilization of forage production by grazing animals further complicates correct interpretation of the success of conversion projects. Hormay (1944) suggested that moderate grazing in the annual type progressively improved range condition and ultimately promoted high livestock weight gains. Grazing either more or less than this moderate level produces changes in both total herbage productivity and relative botanical composition. Heady (1958) postulated that grazing occurs first on taller plants, thereby increasing the relative proportion of shorter plants. On the other hand, complete elimination of grazing animals encourages taller annual plants relative to short plants. Talbot, Biswell, and

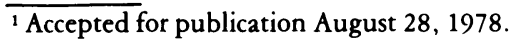


Hormay (1939), Talbot and Biswell (1942), and Jones and Evans (1960) all found that excluding grazing animals in the annual type quickly led to grass dominance, particularly taller species such as ripgut (Bromus rigidus). Biswell (1956) expressed the opinion that this increase in ripgut occurred at the expense of true clovers (Trifolium spp.) and burclover (Medicago hispada), with succession following the order of forbs to wild oats (Avena spp.) to ripgut.

Thus, effective conversion projects require simultaneous consideration of many variables. Herbage productivity, relative botanical composition, and animal productivity are all functions of microsite, annual weather patterns, grazing intensity, and type of cover conversion. Unfortunately, many of the relationships among these variables remain unquantified. Type conversion may be successful on a particular range unit but unsuccessful on a neighboring one supporting similar vegetational communities. Yearly weather patterns account for some inconsistencies, but differences in microsite and grazing intensity also lead to frustrating differences in type conversion results. The purpose of this study was to clarify some of these differences by separating and quantifying as much as possible the impacts of site conditions, weather patterns, and the process of conversion on subsequent annual vegetation.

\section{METHODS OF STUDY}

\section{Watershed II}

The study was conducted at the University of California Hopland Field Station, located in Mendocino County in the central portion of the coast mountain ranges. The experimental area, known as Watershed II, is a fenced 86.2 hectares (ha) drainage basin with a west-flowing drainage into the Russian River. Elevations range from 200 to $430 \mathrm{~m}$. Soils on the watershed, averaging approximately one $m$ thick, overlie sandstone and shale rock of the Franciscan Formation. This formation is extremely shattered and jointed, with intrusions of basic rock and interlaced with faults, very typical of the coastal mountain ranges (Gowans, 1958; Burgy and Papazafiriou, 1974). Identifiable soils on the watershed include eight series: 46 percent Josephine; 28 percent Sutherland/Laughlin complex; 9 percent Maymen; 8 percent Yorkville; 4 percent Laughlin; 3 percent Los Gatos; 1 percent Sutherland; and 1 percent Montara (Burgy and Papazafiriou, 1974).

The climate of the area is subhumid to humid meso-thermal. The winters are mild with occasional frost in valley bottoms, and infrequent, light snowfall at higher elevations. The average annual rainfall approximates $900 \mathrm{~mm}$ with virtually no rain falling between June and September. Fog occurs frequently in valley bottoms during later fall, winter, and early spring, and occasionally during the summer. Average summer and fall temperatures are between $20^{\circ}$ and $25^{\circ} \mathrm{C}$ (Heady, 1956).

Three periods of type conversion were examined on the watershed: calibration period, five years before conversion (1955 to 1959); treatment period, a six-year period initiated by herbicidal treatment of the brush vegetation, and terminated by burning of decaying woody plant debris (1960 to 1965); stabilization period, eight years subsequent to the burn of 1965 (1966 to 1973).

The study began in the spring of 1954 when 63 sheep exclosures, $1 \mathrm{~m}$ in diameter and $0.8 \mathrm{~m}$ in height, constructed of 3.8 centimeters $(\mathrm{cm})$ mesh stucco netting, were located throughout the watershed. The first exclosure was randomly located near the watershed center, and each successive exclosure fell on a predetermined line approximately $25 \mathrm{~m}$ away from the previous exclosure. This line of exclosures extended throughout the watershed, following contours when possible, to achieve two objectives: (1) to facilitate ease of placement, relocation, and sampling of caged areas, and (2) to 
insure that vegetative types of primary interest were represented, while those of little concern in the study, primarily chamise (Adenostoma fasciculatum) without herbaceous understory, were excluded. In addition to 9.3 ha of chamise, the vegetation on Watershed II in 1954 consisted of 5.3 ha of annual, open grassland, principally soft chess (Bromus mollis), silver hairgrass (Aira caryopbyllea), wild oats, nitgrass (Gastridium ventricosum), and filaree (Erodium spp.); 19.8 ha of mixed grass and deciduous oak trees (Quercus lobata); and 50.6 ha of black oak $(Q$. kellogii), live oaks $(Q$. agrifolia, $Q$. wislizenir), blue oak ( $Q$. douglasii) and madrone (Arbutus menziesii).

The stratification of cages within Watershed II resulted in 25 occurring on semi-dense sites characterized by oakwoodland vegetation, while the remaining 38 cages fell on open sites characterized by annual grassland. The semi-dense sites were on predominantly Josephine soils, the open sites primarily on Sutherland/ Laughlin soils.

Moderate sheep grazing, from approximately March 1 through June 1 of each year, began in the spring of 1955 and continued through the summer of 1959 . These five years marked the first, or calibration, period of brush conversion, during which time an average of 72 ewes and their single lambs (approximately 5 acres or 2 ha per animal-unit month) grazed the watershed. Throughout this calibration period vegetation was sampled twice each year-once immediately before grazing, and again immediately after grazing in June. Standing crop was estimated by clipping $0.1 \mathrm{~m}^{2}$ of herbage to ground level (subsequently oven-dried and weighed) at each location. Botanical composition, cover, and height of annual vegetation were estimated in March and again in June with 30 points taken with a ten-point frame. March samples were collected only at outside stakes which marked vegetation selected visually to be similar to vegetation inside the cages. Each stake was placed far enough from its associated cage so that vegetation surrounding the stake was not unduly influ- enced by the trampling activities of curious or hungry sheep congregating about the cages. June samples were collected both inside the cages and at the outside stakes. Sampling outside in June and March occurred on opposite sides of the stake.

Each exclosure was located in a relatively homogenous sampling unit approximately $8 \mathrm{~m}$ in diameter. Exclosures and outside stakes were moved before the March 1 sampling date each year to a different but vegetationally similar spot within each sampling unit. Changes noted in botanical composition or standing crop from one year to the next were therefore not the result of repeated sampling on the same location.

Heady (1957) studied the effect of these exclosures on annual vegetation at the Hopland Field Station, and concluded that by the time of plant maturity, the cage effect on herbage productivity, relative percent botanical composition, and foliar cover became insignificant. Comparisons of these factors on Watershed II, obtained from exclosures sampled in March and June, are therefore valid.

The second, or treatment, period of brush and tree conversion on the watershed, when woody vegetation was converted to grassy vegetation, began in December of 1959 (fig. 1). The trees were killed by applying 2, 4-D amine in surface cuts circling the base of the tree trunks. This procedure required approximately four months to treat all trees on the watershed and was concluded in April of 1960 .

Deciduous trees treated early in the winter generally did not come into leaf the following spring. Those treated later in the winter did come into leaf the following spring but typically lost their leaves by September of 1960 .

The evergreen madrone and live oaks shed their leaves gradually and were bare within a year following treatment. During the second year after treatment many small limbs fell, and within three years following treatment many of the small tree trunks had rotted and the trees were falling. By the end of 1964 , over 50 percent of the trees had fallen, and a heavy 

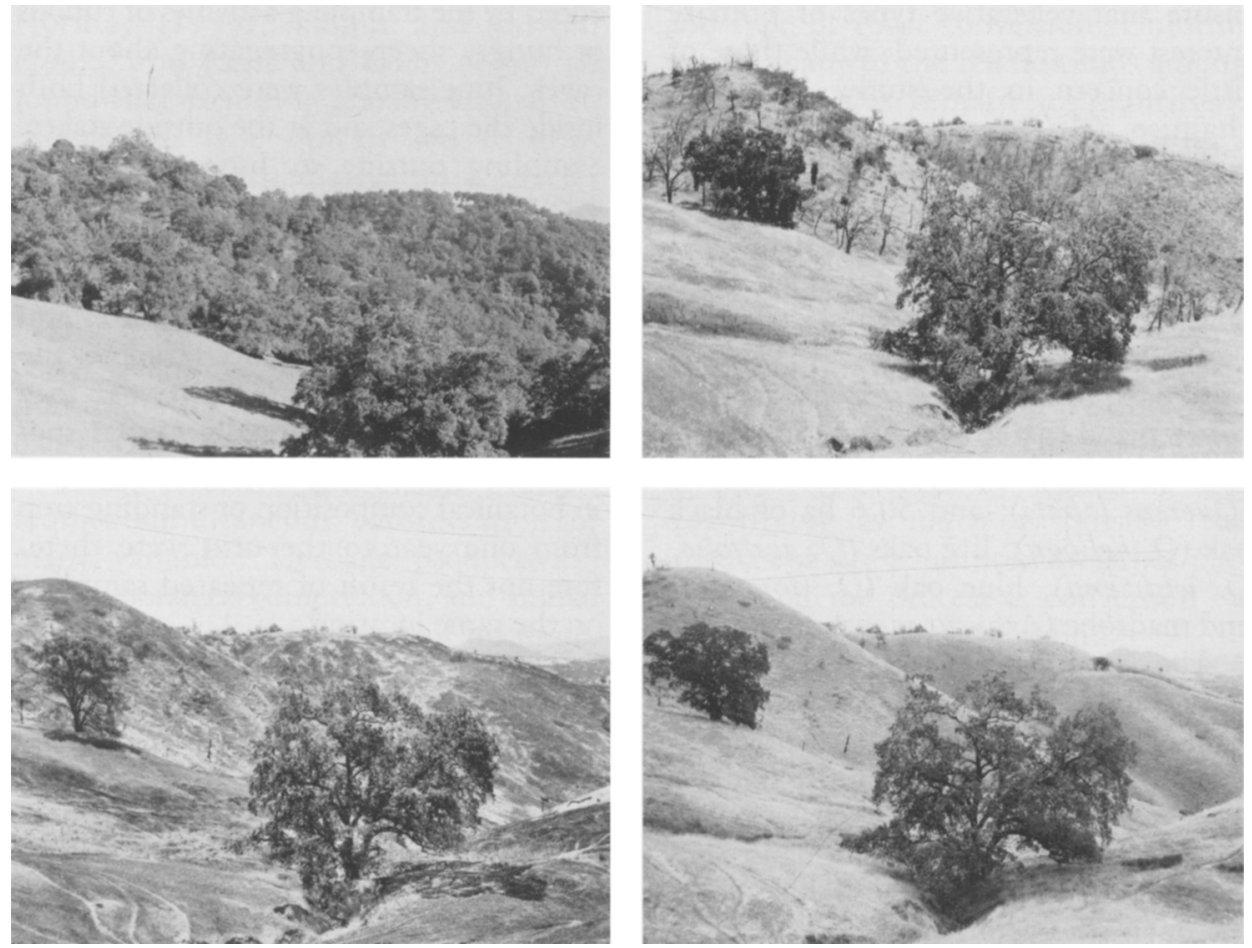

Fig. 1. Watershed II on the Hopland Field Station. Upper left, May 6, 1958, shows the mosaic of annual grassland and various densities of oak woodland before treatment. Upper right, May 22, 1965 , some of the dead oak trees still standing five years after chemical treatment in 1959-60. Lower left, August 10, 1965, was taken three weeks after the fire. Lower right, June 6, 1967, shows two intentionally preserved oak trees and almost complete type conversion to annual grassland.

litter lay on the ground, limiting access for both man and livestock.

In the winter of 1960-1961 forage availability had obviously increased as a result of the reduction in woody plant cover. Consequently, an increase in total animal units was desired for fuller utilization of this increased forage. The method of determining sheep numbers each grazing season was designed to preserve the same grazing intensity, measured as mulch at the end of each spring period, that existed during the calibration period of the study. The amount $\left(\mathrm{g} / \mathrm{m}^{2}\right)$ of available forage determined at the March sample each year subsequent to brush conversion was compared to the average amount of forage available at the March sample throughout the calibration period. The number of sheep (animal units) grazed on the watershed was then altered from 72 (calibration period average) by the same per- centage that the current March 1 figure for herbage/productivity differed from the average herbage productivity during calibration.

This technique insured that grazing intensity, measured as the amount of mulch or litter remaining at the end of each grazing season, was similar from one year to the next.

In the spring of 1960 , ten more exclosures were established on formerly dense sites that were characterized by very thick woodland before type conversion. Virtually no herbaceous understory existed in this woodland before tree poisoning.

During the vegetational conversion treatment period (1960 to 1965), herbage productivity, botanical composition, and plant height were sampled in the same fashion described above. No sheep grazing occurred in 1960 during herbicidal treatment of the woody vegetation. Sheep 
grazing was also halted during the 1965 grazing season to provide abundant grass cover to carry a fire scheduled for that summer.

July, 1965, marked the beginning of the third, or stabilization, period of brush conversion. It was initiated by burning the watershed to remove the extensive buildup of decaying woody vegetation.

Two crews began at the top of the watershed and set fires as they traveled downhill around the periphery (fig. 2). When the crews reached the bottom of the watershed, a safe, burned boundary strip encircled most of the watershed. Center firing occurred before the perimeter fire was completely closed. Center and perimeter fires generated intense heat, producing a firestorm with a convective column of smoke rising approximately $1,300 \mathrm{~m}$ above the ground. This column caused a strong indraft of air from the periphery of the watershed, minimizing the chances of fire escape. Within one hour of center firing, the entire burn, with excellent fuel combustion, was complete.

Herbage productivity, botanical composition, cover and height of the annual vegetation were sampled in the same fashion described above until the stabilization period of brush conversion terminated in June of 1973.

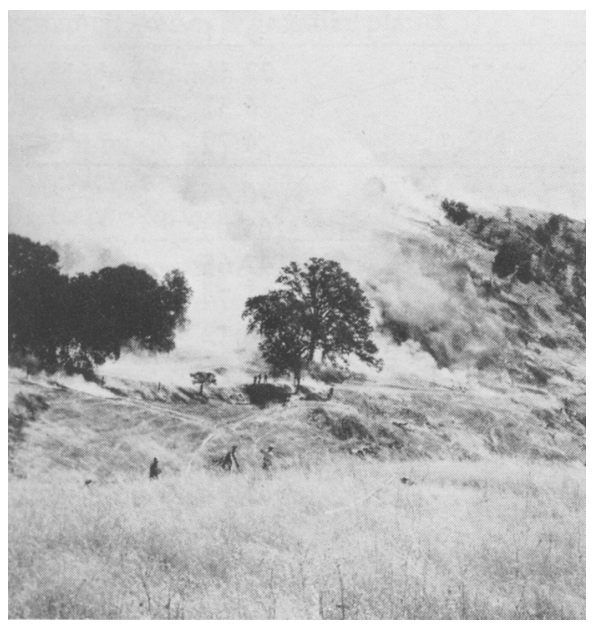

Fig. 2. The prescribed fire, July 20, 1965, burned slowly downhill and toward the center of the watershed.

\section{Methods on the sheep/ deer pastures}

Observed trends in herbage productivity and botanical composition on the watershed following brush conversion may have resulted from variable annual weather patterns as well as the conversion process per se. Since these two factors operate simultaneously on the watershed, a method in addition to simple analysis of variance for main effects is required to properly evaluate their relative impacts. The sheep/deer experimental pastures, also located on the Hopland Field Station, fulfilled this purpose.

Trends in herbage productivity and botanical composition for ungrazed June vegetation, as a result of brush conversion on the watershed, should be different from these same trends observed on the sheep/deer pastures that did not undergo vegetational conversions of any kind. If, however, similar trends were observed on both Watershed II and the sheep/deer pastures, the effects of annual weather patterns may be the causative factors.

Results of studies in the sheep/deer pastures have been partially presented elsewhere (Heady, 1961). The annual carryover effects of grazing treatments on herbage productivity and botanical composition within the caged and uncaged vegetation were minimal. Therefore, changes in these factors from one year to the next, particularly in caged vegetation, are primarily determined by annual weather patterns. In other words, comparison of ungrazed June vegetation on the sheep/deer pastures to ungrazed June vegetation on the watershed provides a means of separating the effects of weather from the effects of brush conversion on Watershed II. The impact of annual weather patterns should produce similar trends in botanical composition and herbage productivity on both the watershed and the sheep/deer pastures. The absolute values for botanical composition and herbage productivity at either of these two locations are not important for evaluating the direction of these trends. 


\section{INFLUENCE OF SITE ON ANNUAL VEGETATION}

The impacts of site and type conversion as determined by analysis of variance are shown in table 1.

While all plant species were recorded during the study of Watershed II and the sheep/deer pastures, only 26 vegetative groups were analyzed in this study. These 26 groups, some consisting of individual species, were selected on the basis of the following three characteristics: (1) the vegetative group, such as annual fescues (Festuca spp.), comprised a consistent, significant portion of the annual vegetation; (2) the vegetative group, such as goldfields (Baeria chrysostoma), is an ecological indicator of overgrazing and/or disturbance; and (3) the vegetative group, such as soft chess, is managerially important in terms of nutritional value for livestock.

The terms open, semi-dense, and dense refer to the tree overstory on Watershed II before type conversion. The open sites supported only herbaceous vegeta-

TABLE 1.

ANALYSIS OF VARIANCE FOR BOTANICAL COMPOSITION, COVER, AND STANDING CROP AS INFLUENCED BY SITE AND TYPE CONVERSION ON WATERSHED II, HOPLAND FIELD STATION

\begin{tabular}{|c|c|c|c|c|}
\hline \multirow[b]{2}{*}{ Vegetative group } & \multicolumn{2}{|c|}{ Influence of site } & \multicolumn{2}{|c|}{ Influence of conversion } \\
\hline & F Ratio & Significance & F Ratio & Significance \\
\hline Aira caryophyllea & 25.66 & 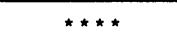 & 203.74 & $\star * \star *$ \\
\hline Avena barbata & 8.43 & 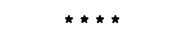 & 57.88 & $\star \star \star \star *$ \\
\hline Bromus mollis & 11.11 & $\star \star \star \star$ & 39.46 & $\star \star \star \star \star$ \\
\hline B. rigidus & 115.26 & $\star \star \star \star \star$ & 15.35 & $\star \star \star \star *$ \\
\hline B. rubens & 7.11 & 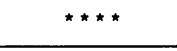 & 6.91 & 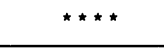 \\
\hline Festuca spp. & 2.11 & * & 243.52 & $\star \star \star \star \star$ \\
\hline Gastridium ventricosum & 7.62 & $\star \star \star \star \star$ & 11.47 & $\star \star \star \star \star$ \\
\hline Hordeum spp. & 4.55 & $\star \star \star *$ & 14.18 & $\star \star \star \star *$ \\
\hline Other annual grasses & 6.30 & $\star \star \star \star *$ & 13.10 & $\star \star \star \star \star$ \\
\hline Perennial grasses \& grasslike plants & 51.28 & $\star \star \star \star$ & 75.66 & $\star \star \star \star$ \\
\hline Medicago hispida & 9.94 & $\star \star \star \star$ & 4.08 & $* \star *$ \\
\hline Trifolium spp. & 2.82 & * * & 2.31 & ** \\
\hline Vicia spp. & 30.22 & $\star \star \star \star$ & 22.36 & $\star \star \star \star$ \\
\hline Other legumes & 11.05 & $* \star * *$ & 6.31 & $\star \star \star \star *$ \\
\hline Baeria chrysostoma & 1.15 & NS & 4.79 & $\star \star \star \star *$ \\
\hline Carduus pycnocephalus & 29.24 & $\star \star \star \star *$ & 76.45 & $\star \star \star \star \star$ \\
\hline Daucus pusillus & 17.96 & 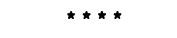 & 165.03 & $\star \star \star \star$ \\
\hline Erodium spp. & 49.94 & $\star \star \star \star$ & 142.63 & $\star \star \star \star$ \\
\hline Geranium spp. & 0.93 & NS & 31.74 & $\star \star \star \star *$ \\
\hline Hypochoeris glabra & 5.30 & $\star \star \star \star$ & 78.12 & $\star \star \star * *$ \\
\hline Other perennial forbs & 0.74 & NS & 5.58 & $\star \star \star \star *$ \\
\hline Other early annual forbs & 14.65 & $\star \star \star \star$ & 84.69 & $\star \star \star *$ \\
\hline Other late annual forbs & 0.36 & NS & 13.98 & $\star \star \star \star *$ \\
\hline Unknown forbs & 1.80 & * & 65.30 & $\star \star \star \star \star$ \\
\hline Cover & 29.41 & $\star * \star *$ & 730.72 & $\star \star \star \star *$ \\
\hline Standing crop & 14.49 & $\star \star \star \star \star$ & 513.64 & $\star \star \star \star *$ \\
\hline
\end{tabular}

NS Not significant.

* Significant at $20 \%$ level.

* * Significant at $10 \%$ level.

** Significant at $5 \%$ level.

**** Significant at $1 \%$ level. 
tion, the dense sites sustained woody vegetation with virtually no herbaceous understory, and the semi-dense sites maintained a mixture of scattered woody and herbaceous vegetation. The vegetational characteristics of these three sites, averaged over all levels of brush conversion, grazing treatments, and season (table 2) are as follows:

\section{Open sites}

Standing crop on the open sites averaged $184 \mathrm{~g} / \mathrm{m}^{2}$, while cover equaled 43 percent (table 2). Annual grasses com- prised 44.4 percent of the vegetative cover, while forbs and legumes contributed 40.7 and 12.3 percent, respectively, of the total cover. The annual grasses consisted primarily of soft chess (20.2 percent), while true clovers ( 5.3 percent) and filaree ( 15.8 percent) dominated the legumes and other non-leguminous annual forbs.

\section{Semi-dense sites}

Standing crop on the semi-dense sites averaged 162.5 grams per square meter, while cover totaled 40.5 percent. The

TABLE 2.

AVERAGE PERCENT BOTANICAL COMPOSITION OF VEGETATIVE GROUPS, COVER AND STANDING CROP ON THE OPEN, SEMI-DENSE AND DENSE SITES OF WATERSHED II, HOPLAND FIELD STATION, 1955 to 1973. *

\begin{tabular}{|c|c|c|c|c|}
\hline Vegetative group & Open sites & $\begin{array}{l}\text { Semi-dense } \\
\text { sites }\end{array}$ & Dense sites & $\begin{array}{l}\text { Least sig. } \\
\text { difference }\end{array}$ \\
\hline & & percent & & $\alpha=0.05$ \\
\hline $\begin{array}{l}\text { Aira caryophyllea } \\
\text { Avena barbata } \\
\text { Bromus mollis } \\
\text { B. rigidus } \\
\text { B. rubens } \\
\end{array}$ & $\begin{array}{r}4.5 \\
6.5 \\
20.2 \\
5.4 \\
0.3 \\
\end{array}$ & $\begin{array}{r}4.0 \\
4.8 \\
19.4 \\
4.5 \\
0.8 \\
\end{array}$ & $\begin{array}{r}0.2 \\
6.8 \\
14.6 \\
15.4 \\
0.5 \\
\end{array}$ & $\begin{array}{l}0.01 \\
0.01 \\
0.02 \\
0.01 \\
0.00\end{array}$ \\
\hline $\begin{array}{l}\text { Festuca spp. } \\
\text { Gastridium ventricosum } \\
\text { Hordeum spp. } \\
\text { Other annual grasses } \\
\text { Perennial grasses \& grasslike plants }\end{array}$ & $\begin{array}{l}7.7 \\
1.2 \\
0.9 \\
0.9 \\
2.3\end{array}$ & $\begin{array}{l}8.2 \\
1.2 \\
0.5 \\
1.6 \\
3.2\end{array}$ & $\begin{array}{l}9.4 \\
0.1 \\
0.0 \\
1.3 \\
8.3\end{array}$ & $\begin{array}{l}0.02 \\
0.00 \\
0.01 \\
0.01 \\
0.01\end{array}$ \\
\hline $\begin{array}{l}\text { Medicago bispida } \\
\text { Trifolium spp. } \\
\text { Vicia spp. } \\
\text { Other legumes } \\
\text { Baeria chrysostoma } \\
\end{array}$ & $\begin{array}{l}1.8 \\
5.3 \\
1.6 \\
2.6 \\
0.2 \\
\end{array}$ & $\begin{array}{l}2.4 \\
5.3 \\
1.4 \\
4.0 \\
0.1 \\
\end{array}$ & $\begin{array}{l}0.2 \\
3.8 \\
5.2 \\
1.3 \\
0.0\end{array}$ & $\begin{array}{l}0.01 \\
0.01 \\
0.01 \\
0.01 \\
0.00 \\
\end{array}$ \\
\hline $\begin{array}{l}\text { Carduus pycnocephalus } \\
\text { Daucus pusillus } \\
\text { Erodium spp. } \\
\text { Geranium spp. } \\
\text { Hypochoeris glabra } \\
\end{array}$ & $\begin{array}{r}0.7 \\
3.0 \\
15.8 \\
1.9 \\
3.7 \\
\end{array}$ & $\begin{array}{r}0.8 \\
3.8 \\
13.8 \\
1.9 \\
3.9 \\
\end{array}$ & $\begin{array}{l}2.8 \\
1.0 \\
4.3 \\
2.4 \\
1.9\end{array}$ & $\begin{array}{l}0.00 \\
0.01 \\
0.02 \\
0.01 \\
0.01\end{array}$ \\
\hline $\begin{array}{l}\text { Other perennial forbs } \\
\text { Other early annual forbs } \\
\text { Other late annual forbs } \\
\text { Unknown forbs } \\
\text { Cover } \\
\text { Standing crop }\left(\mathrm{g} / \mathrm{m}^{2}\right)\end{array}$ & $\begin{array}{r}1.5 \\
6.8 \\
1.5 \\
2.0 \\
43.0 \\
184.1 \\
\end{array}$ & $\begin{array}{r}1.7 \\
7.5 \\
1.6 \\
2.2 \\
40.5 \\
162.5 \\
\end{array}$ & $\begin{array}{r}1.7 \\
11.4 \\
1.7 \\
2.9 \\
37.1 \\
173.2 \\
\end{array}$ & $\begin{array}{l}0.01 \\
0.02 \\
0.01 \\
0.01 \\
1.53 \\
1.14\end{array}$ \\
\hline
\end{tabular}

*Values represent averages for grazed and ungrazed vegetation during all three treatment periods at both the March and June sampling dates. 
relative contribution of plant groups to this cover consisted of 45.0 percent annual grasses, 13.1 percent legumes, and 37.3 percent nonleguminous forbs. Soft chess, 19.4 percent of the vegetative cover, comprised the largest proportion of annual grasses on the semi-dense sites. True clovers and filaree, 5.3 and 13.8 percent, respectively, also were present in significant numbers on the semi-dense sites.

\section{Dense sites}

In contrast to the open sites, relatively low values for standing crop (173.2 grams per square meter) and cover (37.1 percent) occurred on the dense sites. Annual grasses comprised 48.3 percent of the vegetative cover, while legumes and nonleguminous forbs totaled 10.5 and 30.1 percent, respectively (table 2 ).

Unlike the open and semi-dense sites, ripgut (15.4 percent) and soft chess (14.6 percent), together comprised a relatively large proportion of annual grasses on the dense sites in terms of the total vegetative cover. Additionally, true clovers did not dominate leguminous plants as they did on the open and semi-dense sites, as vetches (Vicia spp.), 5.2 percent, comprised the largest proportion of legumes on the dense sites. Although filaree (4.3 percent) formed the largest proportion of non-leguminous forbs in terms of vegetative cover on the dense sites, Italian thistle (Carduus pycnocephalus) 2.8 percent, and geranium (Geranium spp.) 2.4 percent, also attained relatively high proportions.

Goldfields, a forb characteristically found in disturbed or overgrazed stiuations, virtually never appeared on the dense sites (table 2).

\section{Comparisons of sites}

The open sites produced the greatest standing crop on the watershed, followed by the dense and semi-dense sites, respectively, with absolute (though small) differences, significant at $\mathrm{p}<0.01$. Although the dense sites were only slightly less productive than the open sites and

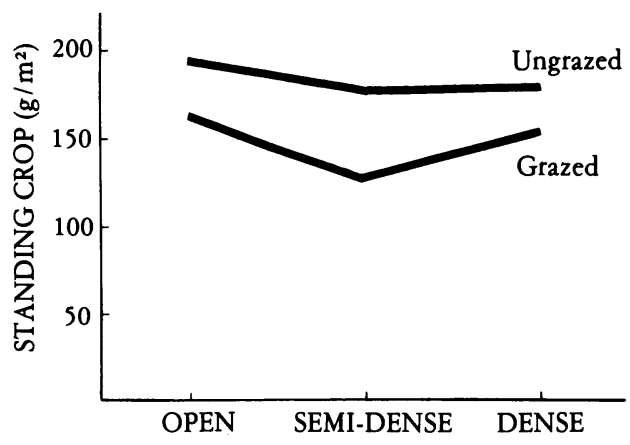

Fig. 3. Influence of two grazing treatments and three types of sites on standing crop $\left(\mathrm{g} / \mathrm{m}^{2}\right)$ on Watershed II, Hopland Field Station, 1955-1973.

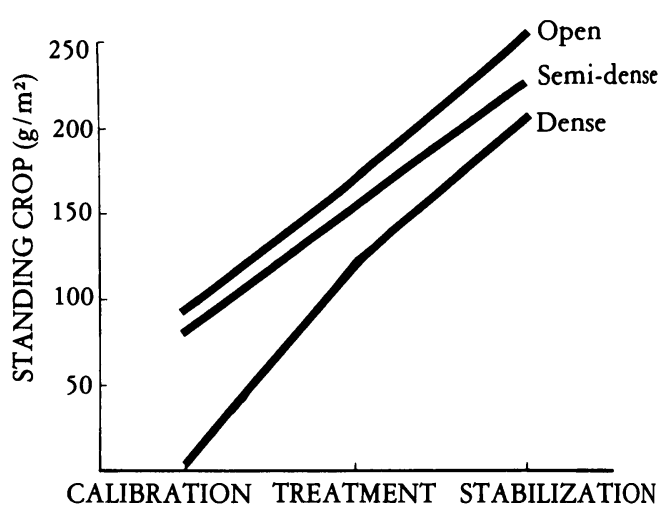

Fig. 4. Influence of three types of sites on standing crop $\left(\mathrm{g} / \mathrm{m}^{2}\right)$ during brush conversion periods on Watershed II, Hopland Field Station, 1955-1973.

more productive than the semi-dense sites, when averaged over both grazed and ungrazed vegetation (table 2), these dense sites produced much less forage than the open sites and were no more productive than the semi-dense sites when measured in ungrazed vegetation only (fig. 3). This comparison of standing crop in ungrazed vegetation provides a better estimate of the influence of site potential than does a comparison including grazed vegetation. Grazing seldom removes the same proportion of herbage from all sites in a pasture. Like standing crop, cover was greatest on the open sites and less on the semi-dense and dense sites, respectively (table 2). 
The combined influences of site and type conversion provide an additional illustration of the impact of site on standing crop (fig 4). Although standing crop increased from virtually zero before conversion to more than $107.6 \mathrm{~g} / \mathrm{m}^{2}$ following treatment of the dense sites, these sites still produced less forage than either the open or semi-dense sites during all periods of the study. Indeed, those sites characterized as open grassland before conversion remained the most productive grassland sites throughout the study on Watershed II.

Before type conversion, the open sites supported herbaceous vegetation, the dense sites woody vegetation with virtually no herbaceous understory, while a mixture of woody and herbaceous vegetation occurred on the semi-dense sites. Therefore, standing crop and cover on each site following conversion completely correlated with the degree of grassland (herbaceous vegetation) on each site before the woody plant treatment. Following conversion, the open sites of Watershed II continued to sustain a more productive grassland than existed on those sites originally supporting woody vegetation.

Although the dense sites produced less standing crop than either the semi-dense or open sites, tall annual grasses, such as wild oats and ripgut, attained maximum botanical composition on these dense sites. Shorter annual grasses, such as nitgrass and silver hairgrass, contributed only slightly to botanical composition on dense sites (table 2).

Foxtails and barleys (Hordeum spp.), most abundant on the open sites (table 2), occurred nearly exclusively in areas of animal concentration, such as resting and bedding grounds. These areas on the watershed coincidentally occurred on the open sites.

Legumes produced a pattern similar to that of annual grasses in response to site. The relatively tall vetches were most abundant on the dense sites, while the more decumbent bur-clover and short true clovers all attained greatest botanical composition on the open sites.

Rattlesnake weed (Daucus pusillus), filaree, and smooth cat's ear, all relatively small plants characteristic of disturbed, open conditions, paralleled the patterns displayed by short annual grasses and legumes as they all contributed much less to botanical composition on the dense sites compared to open and semi-dense sites (table 2). Although filaree grows upright in tall, ungrazed vegetation, its typical growth form is a low-growing, rosette-forming plant in shorter vegetation. Alternatively, biennial Italian thistle, taller than the annual forbs discussed above, achieved maximum botanical compostition on dense sites compared to open or semi-dense sites (table 2).

The dense sites were located primarily on north-facing slopes near the central portion of the watershed. The northfacing dense sites provided the greatest reservoir of soil moisture, occurred on relatively deep soils, and provided amelioration of temperature and moisture extremes throughout the growing season. Apparently these characterisitcs encouraged maximum growth and therefore relative dominance by taller annual grasses, and taller annual, biennial, and perennial forbs (wild oats, ripgut, vetches, Italian thistle) on the dense sites. Shorter annual plants (nitgrass, silver hairgrass, rattlesnake weed, filaree, smooth cat's ear, bur-clover, true clovers) necessarily attained their greatest predominance on the open and semi-dense sites. 


\section{INFLUENCE OF TYPE CONVERSION ON ANNUAL VEGETATION}

\section{Calibration period of type conver- sion (1955 to 1959)}

Standing crop during the calibration period averaged 89.3 grams per square meter, while cover measured 45.3 percent (table 3). Annual grasses furnished 53.6 percent of this vegetative cover, while legumes and other non-leguminous forbs contributed 9.7 and 34.8 percent of the vegetative cover, respectively. A single plant species, soft chess, totaled nearly one quarter (24.0 percent) of this cover, which also included 10.1 percent silver hairgrass, 7.5 percent filaree, and 6.9 percent ripgut. Italian thistle virtually never appeared during the calibration phase of the study, while barleys and foxtails averaged only 0.1 percent of the vegetative cover.

\section{Treatment period of type conver- sion (1960 to 1965)}

Cover during the treatment period averaged only 27.8 percent, while standing crop averaged $159.2 \mathrm{~g} / \mathrm{m}^{2}$. Nonleguminous forbs, 42.8 percent, comprised the largest proportion of all plants present, while annual grasses and legumes contributed 38.2 percent and 14.4 percent of the vegetative cover, respectively. Soft chess and filaree, 20.0 and 11.8 percent, respectively, furnished the largest proportions of this cover on an individual species basis. Additional species contributing significant portions to total cover included smooth cat's ear, true clovers, and ripgut-6.7, 5.8, and 5.3 percent, respectively.

\section{Stabilization period of type con- version (1966 to 1973)}

Relatively high values prevailed during the stabilization period for both standing crop, $237.8 \mathrm{~g} / \mathrm{m}^{2}$, and cover, 48.8 percent (table 3 ). This vegetative cover consisted of 48.3 percent annual grasses, 12.6 percent legumes, and 33.0 percent

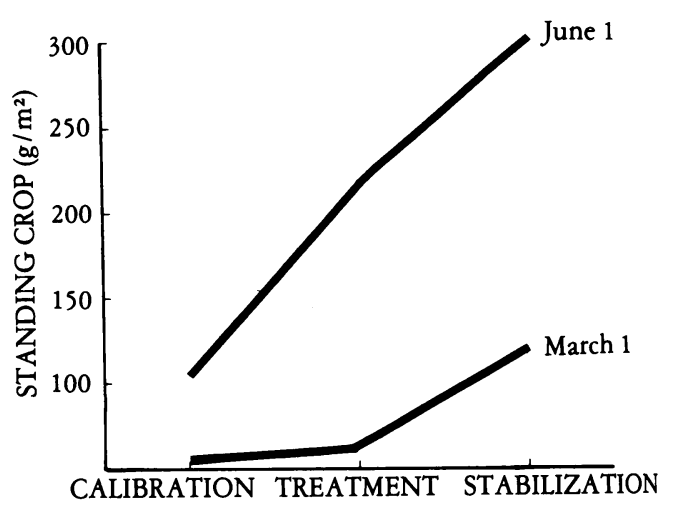

Fig. 5. Influence of two sampling dates on standing crop $\left(\mathrm{g} / \mathrm{m}^{2}\right)$ during brush conversion periods on Watershed II, Hopland Field Station, 1955-1973.

non-leguminous forbs. Filaree, soft chess, and annual fescues contributed 19.3, 16.2 , and 14.0 percent, respectively, thus predominating over all other plant species. Wild oats, 8.2 percent, and perennial grasses and grasslike plants, 5.6 percent, also proliferated during the stabilization period of brush conversion.

\section{Comparisons of calibration, treat-} ment, and stabilization periods

Standing crop increased during each succeeding conversion period on the watershed and ultimately reached levels more than 200 percent higher during the stabilization period than during the calibration period before conversion. The greatest proportion of this dramatic increase in standing crop occurred during the period of rapid growth in March, April, and early May. Type conversion produced a much smaller increase in standing crop before this period, beginning approximately March 1 at the Hopland Field Station ( $p<0.01$; fig. 5). In contrast to standing crop, total vegetative cover declined on the watershed during the treatment period but returned to preconversion values during the stabilization period following type conversion (table 3). 
TABLE 3.

AVERAGE PERCENT BOTANICAL COMPOSITION OF VEGETATIVE GROUPS, COVER AND STANDING CROP DURING THREE PERIODS OF TYPE CONVERSION ON WATERSHED II, HOPLAND FIELD STATION, 1955 to 1973. *

\begin{tabular}{|c|c|c|c|c|}
\hline Vegetative group & Calibration & Treatment & Stabilization & $\begin{array}{l}\text { Least sig. } \\
\text { difference }\end{array}$ \\
\hline & & percent & & $\alpha=0.05$ \\
\hline Aira caryophyllea & 10.1 & 2.8 & 1.2 & 0.01 \\
\hline Avena barbata & 4.9 & 3.3 & 8.2 & 0.01 \\
\hline Bromus mollis & 24.9 & 20.0 & 16.2 & 0.02 \\
\hline Bromus rigidus & 6.9 & 5.3 & 5.9 & 0.01 \\
\hline Bromus rubens & 0.8 & 0.5 & 0.3 & 0.00 \\
\hline Festuca spp. & 3.2 & 3.6 & 14.0 & 0.01 \\
\hline Gastridium ventricosum & 1.6 & 1.4 & 0.6 & 0.00 \\
\hline Hordeum spp. & 0.1 & 0.3 & 1.1 & 0.00 \\
\hline Other annual grasses & 2.0 & 1.0 & 0.8 & 0.00 \\
\hline Perennial grasses \& grasslike plants & 1.3 & 1.2 & 5.6 & 0.01 \\
\hline Medicago hispida & 1.8 & 2.4 & 1.5 & 0.01 \\
\hline Trifolium spp. & 4.9 & 5.8 & 4.9 & 0.01 \\
\hline Vicia spp. & 0.1 & 2.0 & 2.8 & 0.01 \\
\hline Other legumes & 2.9 & 4.2 & 3.4 & 0.01 \\
\hline Baeria chrysostoma & 0.1 & 0.4 & 0.1 & 0.00 \\
\hline Carduus pycnocephalus & 0.0 & 0.1 & 2.1 & 0.00 \\
\hline Daucus pusillus & 6.4 & 3.8 & 0.6 & 0.01 \\
\hline Erodium spp. & 7.5 & 11.8 & 19.3 & 0.02 \\
\hline Geranium spp. & 3.0 & 2.4 & 0.9 & 0.01 \\
\hline Hypochoeris glabra & 1.7 & 6.7 & 2.7 & 0.01 \\
\hline Other perennial forbs & 2.1 & 1.5 & 1.3 & 0.01 \\
\hline Other early annual forbs & 7.9 & 11.6 & 4.3 & 0.01 \\
\hline Other late annual forbs & 1.9 & 2.1 & 0.9 & 0.01 \\
\hline Unknown forbs & 4.2 & 2.4 & 0.8 & 0.01 \\
\hline Cover & 45.3 & 27.8 & 48.8 & 1.19 \\
\hline Standing crop $\left(\mathrm{g} / \mathrm{m}^{2}\right)$ & 89.3 & 159.2 & 237.8 & 0.88 \\
\hline
\end{tabular}

*Values represent averages for grazed and ungrazed vegetation on all three sites at both March and June sampling dates.

The direct impact of type conversion on subsequent annual vegetation of the watershed is confounded with the concomitant changes in annual weather patterns. Therefore, trends in standing crop, cover, and botanical composition of the annual vegetation during each period of conversion were not necessarily direct functions of vegetational manipulations. While this section of the paper deals specifically with observed vegetational changes during each period of conversion, discussion of and reasons for these changes are postponed until type conver- sion and the impact of weather patterns are evaluated simultaneously.

The influence of type conversion on botanical composition of annual grasses produced a pattern similar to the influence of site on annual grasses. Silver hairgrass, soft chess, and nitgrass, all relatively less abundant on the dense than on the open and semi-dense sites, all declined in percentage botanical composition following conversion $(\mathrm{p}<0.01)$. Silver hairgrass declined from 10.1 percent before conversion to 1.2 percent during the stabilization period following conversion. 
Similarly, soft chess decreased from 24.0 percent to 16.0 percent, while nitgrass declined from 1.6 percent to 0.6 percent (table 3).

Alternatively, wild oats and annual fescues, relatively more abundant on the dense than on the open and semi-dense sites, both increased in percent botanical compostion following removal of woody plants $(\mathrm{p}<0.01)$. As virtually no herbaceous vegetation existed on the dense sites before brush conversion, this change in vegetative cover obviously encouraged those plant species capable of occupying the formerly dense sites following brush removal. Ripgut provided an exception to this generalization, since it declined on the watershed as a whole-even though it attained greatest predominance on the dense sites (tables 2 and 3).

Vetches, like most plant species more abundant on the dense as opposed to the open and semi-dense sites, increased in percent botanical composition following brush conversion from 0.1 to 2.8 percent ( $p<0.01)$. Predictably, the bulk of this increase occurred on formerly dense sites (fig. 6).

Proportions of bur-clover and true clovers remained largely unchanged during the stabilization period compared to the calibration period before brush removal, even though these species increased during the treatment period immediately following brush conversion. Goldfields and smooth cat's ear exhibited trends similar to these legumes $(\mathrm{p}<0.01$; table 3). Apparently these forbs, all relatively more abundant on the open and semidense rather than the dense sites, and all typically associated with disturbed conditions, increased in percent botanical composition only so long as the sitedisturbing impacts of type conversion existed. As soon as the annual vegetation stabilized following conversion, and other taller plant species occupied the dense sites, the contribution to percent botanical composition of these successional species returned to preconversion levels. Alternatively, rattlesnake weed, also characteristically found in open or disturbed conditions, decreased in percent

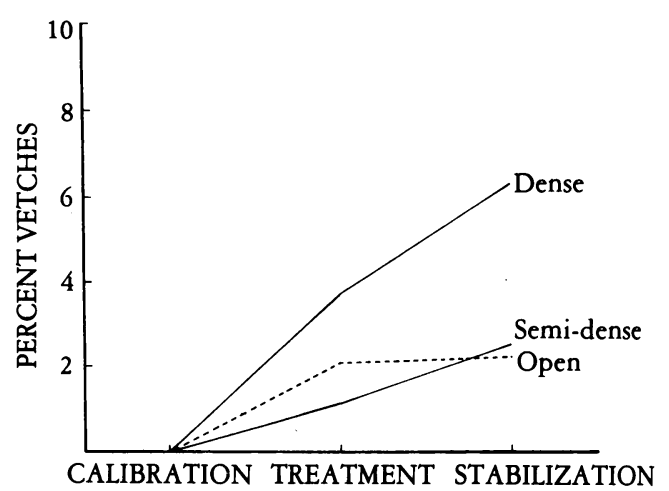

Fig. 6. Influence of three types of sites on proportion of vetches (Vicia spp.) during brush conversion periods on Watershed II, Hopland Field Station, 1955-1973.

botanical composition during each period of brush conversion $(\mathrm{p}<0.01)$. This apparent contradiction may relate to differential impacts of annual weather patterns on these plant species.

Filaree and Italian thistle comprised the only non-leguminous forbs that increased throughout each conversion period on Watershed II. The presence of Italian thistle, virtually nonexistent before conversion but 2.1 percent of the vegetative cover during the stabilization period of conversion, resulted primarily from its invasion of the Hopland Field Station during the course of the study. Italian thistle never appeared in the sampling data until 1964 (Pitt, 1975). However, conversion obviously aided invasion of the watershed by Italian thistle, which appeared consistently in holes and depressions created when the stumps of trees rotted and fell. Although Italian thistle occurred consistently along the edges of sheep trails, particularly on the downhill side, the proportion of this plant in the total has not significantly increased since 1968 (Pitt, 1975).

Perennial grasses, seeded into the watershed in September of 1965, increased from 1.3 percent of the vegetative cover before conversion to 5.6 percent of the cover during the stabilization period (table 4). The greatest increase in botanical composition of these grasses which included orchard grass (Dactylis glomerata) 


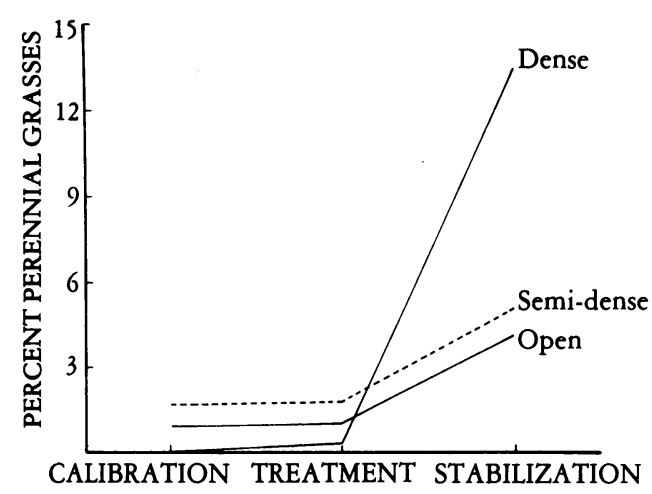

Fig. 7. Influence of three types of sites on proportion of perennial grasses during brush conversion periods on Watershed II, Hopland Field Station, 1955-1973.

and Harding grass (Phalaris tuberosa) occurred on the dense sites, where diminished temperature and moisture extremes may have favored the maintenance of perennial grass species $(p<0.01$; fig. 7) ${ }^{-}$
Grazed vegetation in June during the calibration, treatment, and stabilization periods of conversion averaged 71.0, 157.1 , and $195.8 \mathrm{~g} / \mathrm{m}^{2}$, respectively (Pitt, 1975). These figures indicate that increasing amounts of mulch lay on the ground at the beginning of each growing season during each successive period of type conversion, perhaps because of less grazing pressure. Certainly, increasing quantities of mulch favored taller annual plants relative to shorter annual plants. Therefore, the impact of the conversion process on annual vegetation, within the ameliorating and/or exacerbating influences of annual weather patterns, increased total standing crop on Watershed II by (1) augmenting the total area available for herbaceous vegetation, and (2) promoting increased herbaceous mulch which initiated replacement of shorter annual plants by taller annual plants. The extent of these changes in percent botanical composition and standing crop was more pronounced on some sites than on others.

\section{INFLUENCES OF TYPE CONVERSION AND WEATHER PATTERNS ON ANNUAL VEGETATION}

The impacts of weather patterns and type conversion on subsequent annual vegetation are completely confounded on Watershed II. The observed increase in standing herbaceous crop following conversion may have resulted in part from improved growing conditions, such as increased soil fertility from ashes, as well as fewer woody plants. Fortunately, the combined influences of site and conversion provide a method for evaluating the impacts of conversion versus annual weather patterns.

Changes in standing crop and/or percent botanical composition as a function of conversion should not have occurred on the open sites which supported virtually no woody vegetation before treatment on the semi-dense and dense sites. Similar trends in standing crop, cover, or botanical composition on all three sites (table 4) probably resulted from weather patterns rather than conversion. These combined impacts of site and conversion on annual vegetation, as determined by analysis of variance, are summarized in table 5 .

Data from the sheep/deer pastures on the Hopland Field Station, which did not undergo conversion, enable the use of a second method for evaluating the relative impacts of conversion and weather patterns on annual vegetation of the watershed. When inherent site potential differences between Watershed II and the sheep/deer pastures are minimized by comparing only mature (June), ungrazed vegetation, trends in standing crop, cover, and percent botanical composition on the watershed (table 6) similar to these respective trends on the sheep/deer pastures (table 7) probably resulted from annual weather patterns. If these vegetative trends differed at the two locations, then observed changes in standing crop, cover, and percent botanical composition on the watershed probably resulted from brush conversion. 
TABLE 4.

AVERAGE PERCENT BOTANICAL COMPOSITION OF VEGETATIVE GROUPS, COVER, AND STANDING CROP ON THE OPEN SITES (0), SEMI-DENSE SITES (SD), AND DENSE SITES (D) DURING THE CALIBRATION (C), TREATMENT (T), AND STABILIZATION (S) PERIODS OF BRUSH CONVERSION ON WATERSHED II HOPLAND FIELD STATION, 1955 to $1973^{*}$

\begin{tabular}{|c|c|c|c|c|c|c|c|c|c|}
\hline \multirow[b]{3}{*}{ Aira caryophyllea } & \multirow{3}{*}{$\begin{array}{l}\mathrm{O} / \mathrm{C} \\
10.3\end{array}$} & \multirow{3}{*}{$\begin{array}{r}\mathrm{O} / \mathrm{T} \\
3.6\end{array}$} & \multirow{3}{*}{$\begin{array}{l}\mathrm{O} / \mathrm{S} \\
1.4\end{array}$} & \multicolumn{2}{|c|}{$\mathrm{SD} / \mathrm{C} \mathrm{SD} / \mathrm{T}$} & I SD/S & \multirow[t]{2}{*}{$\mathbf{D} / \mathbf{T}$} & \multirow{2}{*}{$\mathrm{D} / \mathrm{S}$} & \multirow{2}{*}{$\begin{array}{c}\begin{array}{c}\text { Least sig. } \\
\text { difference }\end{array} \\
\alpha=0.05\end{array}$} \\
\hline & & & & \multicolumn{3}{|c|}{ percent } & & & \\
\hline & & & & 9.7 & 2.6 & 1.3 & 0.1 & 0.2 & 0.02 . \\
\hline Avena barbata & 5.1 & 3.3 & 9.6 & 4.7 & 2.8 & 6.4 & 5.4 & 7.8 & 0.02 \\
\hline Bromus mollis & 25.4 & 21.1 & 16.0 & 21.9 & 20.4 & 17.0 & 14.5 & 14.6 & 0.03 \\
\hline B. rigidus & 7.4 & 3.9 & 5.1 & 6.2 & 3.4 & 4.1 & 17.1 & 14.2 & 0.02 \\
\hline & 0.3 & 0.2 & 0.3 & 1.6 & 0.7 & 0.2 & 1.1 & 0.1 & 0.01 \\
\hline Festuca spp. & 3.3 & 3.7 & 13.5 & 3.0 & 3.8 & 15.0 & 2.8 & 13.8 & 0.02 \\
\hline Gastridium ventricosum & 1.6 & 1.4 & 0.8 & 1.5 & 1.9 & 0.6 & 0.3 & 0.0 & 0.01 \\
\hline Hordeum spp. & 0.0 & 0.6 & 1.7 & 0.4 & 0.1 & 0.8 & 0.0 & 0.0 & 0.01 \\
\hline Other annual grasses & 1.6 & 0.3 & 0.8 & 2.6 & 1.6 & 1.0 & 2.5 & 0.4 & 0.01 \\
\hline Perennial grasses \& grasslike plants & 0.9 & 1.0 & 4.1 & 1.8 & 1.8 & 5.1 & 0.3 & 13.5 & 0.02 \\
\hline Medicago hispida & 1.5 & 2.4 & 1.6 & 2.2 & 3.2 & 1.8 & 0.1 & 0.2 & 0.01 \\
\hline Trifolium spp. & 5.1 & 6.4 & 4.8 & 4.7 & 6.0 & 5.1 & 2.3 & 4.8 & 0.02 \\
\hline Vicia spp. & 0.1 & 2.1 & 2.2 & 0.0 & 1.2 & 2.5 & 3.7 & 6.3 & 0.01 \\
\hline Other legumes & 2.3 & 4.8 & 3.6 & 3.8 & 4.4 & 3.9 & 0.9 & 1.5 & 0.01 \\
\hline Baeria chrysostoma & 0.1 & 0.6 & 0.1 & 0.0 & 0.2 & 0.1 & 0.1 & 0.0 & 0.00 \\
\hline Carduus pycnocephalus & 0.0 & 0.2 & 1.5 & 0.0 & 0.0 & 2.0 & 0.0 & 4.6 & 0.01 \\
\hline Daucus pusillus & 6.0 & 3.8 & 0.5 & 7.1 & 4.6 & 0.9 & 1.8 & 0.4 & 0.01 \\
\hline Erodium spp. & 8.1 & 14.7 & 21.7 & 6.6 & 11.3 & 20.3 & 1.1 & 6.4 & 0.03 \\
\hline Geranium spp & 2.7 & 2.3 & 1.0 & 3.4 & 1.7 & 1.0 & 5.2 & 0.6 & 0.01 \\
\hline Hypochoeris glabra & 1.6 & 7.8 & 2.4 & 1.9 & 7.0 & 3.1 & 1.1 & 2.5 & 0.02 \\
\hline Other perennial for & 1.8 & 1.4 & 1.2 & 2.4 & 1.3 & 1.5 & 2.4 & 1.2 & 0.01 \\
\hline Other early an & 8.0 & 8.8 & 4.6 & 7.9 & 11.8 & 4.2 & 23.5 & 3.5 & 0.02 \\
\hline Other lage annual forbs & 2.0 & 2.1 & 0.7 & 1.8 & 2.3 & 1.1 & 1.8 & 1.6 & 0.01 \\
\hline Unknown forbs & 4.1 & 1.9 & 0.8 & 4.4 & 2.0 & 0.8 & 5.8 & 1.0 & 0.01 \\
\hline Cover & 46.4 & 29.6 & 50.0 & 43.6 & 26.8 & 48.1 & 23.4 & 46.1 & 2.23 \\
\hline Standing crop $\left(\mathrm{g} / \mathrm{m}^{2}\right)$ & 94.7 & 171.1 & 254.0 & 80.7 & 153.9 & 225.0 & 124.9 & 204.5 & 1.66 \\
\hline
\end{tabular}

*Values represent averages for grazed and ungrazed vegetation at both the March and June sampling dates.

These two methods (site-conversion interactions and vegetative trends on Watershed II compared to those on the sheep/deer pastures) should provide similar conclusions concerning the relative impacts of conversion and weather patterns on annual vegetation.

Although herbaceous cover increased dramatically on the dense sites following conversion on the watershed, subsequent changes in cover occurred uniformly on the open, semi-dense, and dense sites (fig. 8). Indeed, cover on the open and semi-dense sites exhibited virtually iden- tical directional trends during all three treatment periods. While absolute differences in cover existed among the open, semi-dense, and dense sites, herbaceous cover on all three types of sites apparently responded equally to the impacts of annual weather patterns.

This overriding influence of annual weather patterns on cover as determined by site-conversion interactions is further indicated by similar trends for cover on both Watershed II and the sheep/deer pastures. Not only the direction of these trends but also the absolute value of cover 
TABLE 5 .

ANALYSIS OF VARIANCE FOR BOTANICAL COMPOSITION, COVER PERCENT, AND STANDING CROP AS INFLUENCED BY SITE AND BRUSH CONVERSION ON WATERSHED II, HOPLAND FIELD STATION (1955 to 1973)

\begin{tabular}{|c|c|c|}
\hline Vegetative group & F Ratio & Significance \\
\hline $\begin{array}{l}\text { Aira caryophyllea } \\
\text { Avena barbata } \\
\text { Bromus mollis } \\
\text { B. rigidus } \\
\text { B. rubens }\end{array}$ & $\begin{array}{l}1.81 \\
3.44 \\
1.41 \\
4.94 \\
2.34\end{array}$ & $\begin{array}{c}* \\
* \star * \\
N S \\
\star \star \star \star \\
* \star\end{array}$ \\
\hline $\begin{array}{l}\text { Festuca spp. } \\
\text { Gastridium ventricosum } \\
\text { Hordeum spp. } \\
\text { Other annual grasses } \\
\text { Perennial grasses \& grasslike plants }\end{array}$ & $\begin{array}{r}0.18 \\
2.07 \\
1.24 \\
6.35 \\
35.21 \\
\end{array}$ & $\begin{array}{r}\text { NS } \\
* \\
\text { NS } \\
\star \star \star * \\
* \star \star * \\
\end{array}$ \\
\hline $\begin{array}{l}\text { Medicago hispida } \\
\text { Trifolium spp. } \\
\text { Vicia spp. } \\
\text { Other legumes } \\
\text { Baeria chrysostoma }\end{array}$ & $\begin{array}{l}1.03 \\
5.08 \\
3.80 \\
2.71 \\
2.02 \\
\end{array}$ & $\begin{array}{c}\text { NS } \\
\star \star \star \star \\
* \star \star \\
\star \star \\
* \\
*\end{array}$ \\
\hline $\begin{array}{l}\text { Carduus pycnocephalus } \\
\text { Daucus pusillus } \\
\text { Erodium spp. } \\
\text { Geranium spp. } \\
\text { Hypochoeris glabra }\end{array}$ & $\begin{array}{r}15.83 \\
3.06 \\
1.57 \\
10.10 \\
13.12\end{array}$ & $\begin{array}{l}* \star \star \star \\
\star \star \star \\
N S \\
* \star \star \star \\
* \star \star *\end{array}$ \\
\hline $\begin{array}{l}\text { Other perennial forbs } \\
\text { Other early annual forbs } \\
\text { Other late annual forbs } \\
\text { Unknown forbs } \\
\text { Cover } \\
\text { Standing crop }\left(\mathrm{g} / \mathrm{m}^{2}\right)\end{array}$ & $\begin{array}{r}1.82 \\
36.75 \\
1.40 \\
7.12 \\
0.52 \\
0.26\end{array}$ & $\begin{array}{r}* \\
\star * \star * \\
N S \\
* * * * \\
\text { NS } \\
\text { NS }\end{array}$ \\
\hline $\begin{array}{l}\text { NS Not significant. } \\
\star \quad \text { Significant at } 20 \% \text { level. } \\
\star * \quad \text { Significant at } 10 \% \text { level. }\end{array}$ & $\begin{array}{l}\text { * Signifi } \\
* \quad \text { Signifi }\end{array}$ & $\begin{array}{l}\text { at } 5 \% \text { level. } \\
\text { at } 1 \% \text { level. }\end{array}$ \\
\hline
\end{tabular}

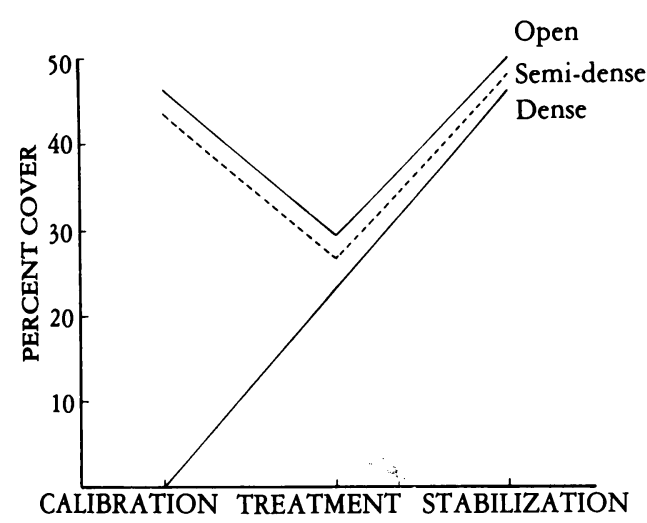

Fig. 8. Influence of three types of sites on percent cover during brush conversion periods on Watershed II, Hopland Field Station, $1955-1973$.

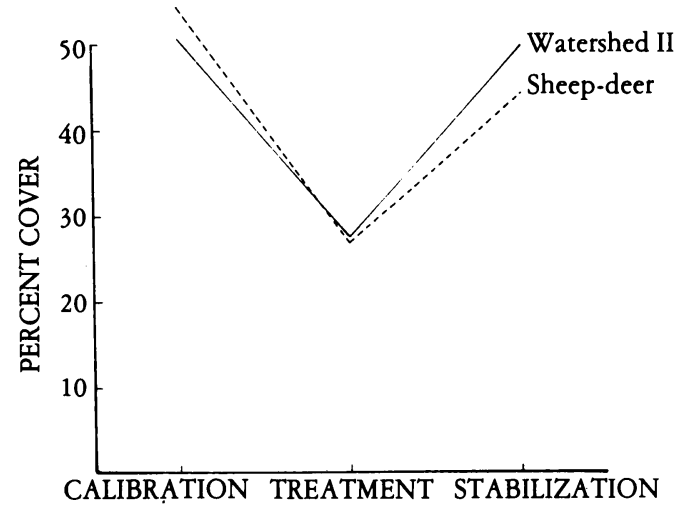

Fig. 9. Changes in percent cover on Watershed II and on sheep/deer pastures during brush conversion periods on Watershed II, Hopland Field Station, 1955-1973. 
TABLE 6.

AVERAGE PERCENT BOTANICAL COMPOSITION OF VEGETATIVE GROUPS, COVER, AND STANDING CROP DURING THREE PERIODS OF BRUSH CONVERSION ON WATERSHED II, HOPLAND FIELD STATION, 1955 to 1973

\begin{tabular}{lccc}
\hline \multicolumn{1}{c}{ Vegetative group } & Calibration & Treatment & Stabilization \\
\hline & & percent & \\
Aira caryophyllea & 14.1 & 4.6 & 1.6 \\
Avena barbata & 4.6 & 3.6 & 8.3 \\
Bromus mollis & 22.2 & 18.4 & 15.3 \\
B. rigidus & 6.1 & 6.2 & 5.5 \\
B. rubens & 1.4 & 0.7 & 0.2 \\
\hline Festuca spp. & 3.0 & 4.2 & 14.4 \\
Gastridium ventricosum & 2.1 & 2.2 & 1.1 \\
Hordeum spp. & 0.2 & 0.6 & 1.4 \\
Other annual grasses & 1.9 & 1.4 & 0.6 \\
Perennial grasses \& grasslike plants & 1.2 & 1.6 & 6.0 \\
\hline Medicago hispida & 2.1 & 2.7 & 1.8 \\
Trifolium spp. & 6.6 & 7.7 & 6.2 \\
Vicia spp. & 0.0 & 4.2 & 5.0 \\
Other legumes & 1.4 & 3.7 & 4.9 \\
Baeriachrysostoma & 0.2 & 0.6 & 2.9 \\
\hline Carduus pycnocephalus & 0.0 & 0.0 & 1.5 \\
Daucus pusillus & 7.2 & 5.0 & 0.6 \\
Erodium spp. & 6.0 & 9.8 & 15.0 \\
Geranium spp. & 0.8 & 0.3 & 0.3 \\
Hypochoeris glabra & 1.5 & 0.9 & 1.0 \\
\hline Other perennial forbs & 1.0 & 0.9 & 1.4 \\
Other early annual forbs & 10.3 & 15.8 & 5.1 \\
Other late annual forbs & 2.9 & 2.6 & 1.0 \\
Unknown forbs & 2.2 & 1.0 & 0.7 \\
Cover & 50.9 & 27.8 & 49.9 \\
Standing crop (g/m ${ }^{2}$ ) & 142.1 & 275.6 & 411.2 \\
\hline
\end{tabular}

on both the watershed and the sheep/ deer pastures were virtually identical throughout the years 1955 through 1973 , inclusive (fig. 9).

Standing crop, as discussed previously, increased tremendously on the dense sites following type conversion on Watershed II. Once this initial increase occurred, however, standing crop on all three sites responded similarly between the treatment and stabilization treatment periods (fig 4). Like cover, standing crop on the open and semi-dense sites exhibited virtually identical trends during the calibration, treatment, and stabilization periods, suggesting very similar soil characteristics between sites. Although absolute differences in standing crop existed among sites on the watershed, standing crop on all three sites responded similarly between the treatment and the stabilization periods of brush conversion.

Unlike cover, however, standing crop on the watershed exhibited a different pattern than standing crop on the sheep/ deer pastures (fig. 10). While increasing at both locations during the treatment period, standing crop continued upward during the stabilization period of conversion on the watershed, but returned to calibration period levels on the sheep/ deer pastures. Thus, the relatively permanent influence of brush conversion on standing crop of Watershed II surmounted the concomitant influences of annual weather patterns partially responsible for the observed decline in standing crop on the sheep/deer pastures. Brush conversion, 
TABLE 7.

AVERAGE PERCENT BOTANICAL COMPOSITION OF VEGETATIVE GROUPS, COVER, AND STANDING CROP ON THE SHEEP/DEER PASTURES DURING THE THREE PERIODS OF BRUSH CONVERSION ON WATERSHED II, HOPLAND FIELD STATION, 1955 to 1973

\begin{tabular}{|c|c|c|c|}
\hline Vegetative group & Calibration & Treatment & Stabilization \\
\hline & \multicolumn{3}{|c|}{ percent } \\
\hline Aira caryophyllea & 13.3 & 4.0 & 15.1 \\
\hline Avena barbata & 4.3 & 3.5 & 2.4 \\
\hline Bromus mollis & 28.3 & 19.5 & 20.0 \\
\hline B. rigidus & 5.6 & 4.0 & 1.6 \\
\hline B. rubens & 3.1 & 1.9 & 1.8 \\
\hline Festuca spp. & 3.8 & 2.8 & 6.9 \\
\hline Gastridium ventricosum & 1.4 & 1.7 & 1.3 \\
\hline Hordeum spp. & 0.5 & 0.2 & 0.1 \\
\hline Other annual grasses & 1.5 & 2.2 & 3.9 \\
\hline Perennial grasses \& grasslike plants & 0.9 & 0.7 & 0.4 \\
\hline Medicago hispida & 0.4 & 1.5 & 0.8 \\
\hline Trifolium spp. & 6.9 & 14.8 & 10.1 \\
\hline Vicia spp. & 0.0 & 0.1 & 0.0 \\
\hline Other legumes & 0.6 & 1.6 & 1.3 \\
\hline Baeria chrysostoma & 0.0 & 0.0 & 0.0 \\
\hline Carduus pycnocephalus & 3.4 & 4.7 & 3.1 \\
\hline Daucus pusillus & 12.6 & 18.6 & 14.6 \\
\hline Erodium spp. & 0.2 & 0.1 & 0.5 \\
\hline Geranium spp. & 0.8 & 0.4 & 2.4 \\
\hline Hypochoeris glabra & 0.4 & 1.3 & 1.0 \\
\hline Other early annual forbs & 5.4 & 7.7 & 6.7 \\
\hline Other late annual forbs & 1.6 & 1.8 & 1.0 \\
\hline Unknown forbs & 0.5 & 0.4 & 1.2 \\
\hline Cover & 54.4 & 27.1 & 44.3 \\
\hline Standing crop $\left(\mathrm{g} / \mathrm{m}^{2}\right)$ & 214.2 & 241.1 & 223.9 \\
\hline
\end{tabular}

therefore, certainly produced part of the observed increase in herbaceous standing crop on the watershed, particularly on the dense sites which supported virtually no forage before conversion.

Trends in percent composition of soft chess and annual fescues following conversion on the watershed occurred similarly on all sites (site-conversion interaction non-significant at the 20 percent level of significance, table 5). Additionally these plant species displayed similar directional trends in composition in ungrazed June vegetation on both the watershed (table 6) and the sheep/deer pastures (table 7). Therefore, observed trends in composition for these plant species were at least partly initiated and/or maintained

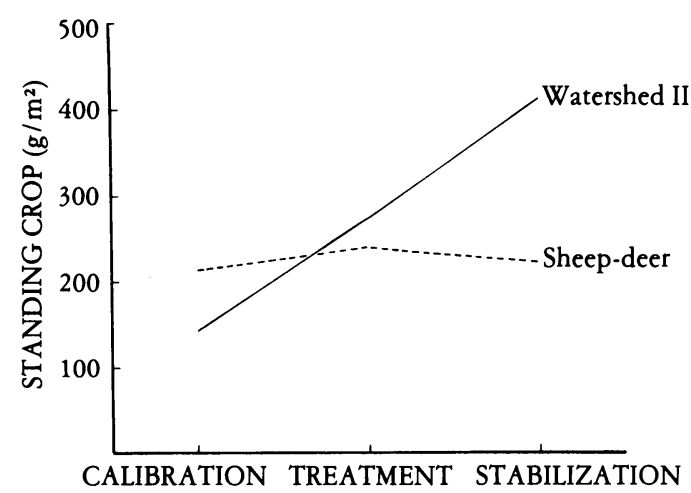

Fig. 10. Changes in standing crop $\left(\mathrm{g} / \mathrm{m}^{2}\right)$ on Watershed II and on sheep/deer pastures during brush conversion periods on Watershed II, Hopland Field Station, 1955-1973. 
by annual weather patterns rather than conversion.

In contrast to soft chess and annual fescues, changes in percent botanical composition for silver hairgrass $(p<0.20)$, wild oats $(\mathrm{p}<0.05)$, ripgut $(\mathrm{p}<0.01)$, and nitgrass $(\mathrm{p}<0.20)$ did not occur equally on the open, semi-dense, and dense sites following brush conversion on Watershed II (table 4). Moreover, all of these plant species displayed different trends in percent botanical composition on the watershed (table 6) than on the sheep/deer pastures (table 7). Silver hairgrass decreased on the watershed from 14.1 percent to 1.6 percent during the calibration and stabilization periods of brush conversion, respectively, but remained virtually unchanged on the sheep/deer pastures. Similarly the proportion of wild oats doubled on the watershed, but decreased in the sheep/deer pastures. Ripgut declined from 6.1 percent to 5.5 percent on the watershed during the calibration and stabilization periods of brush conversion, while during the same period on the sheep/deer pastures this species declined much more drastically from 5.6 to 1.6 percent. Nitgrass remained unchanged on the sheep/deer pastures but declined by half from 2.1 to 1.1 percent of the vegetative cover on the watershed during the calibration and stabilization periods of conversion, respectively.

These different trends on the watershed and sheep/deer pastures, combined with statistically significant site-conversion interactions on the watershed, all suggest that conversion, rather than annual weather patterns initiated the changes in botanical composition observed on Watershed II for silver hairgrass, wild oats, ripgut, and nitgrass.

Changes in proportion of bur-clover and true clovers following conversion on Watershed II were largely unaffected by site (site-conversion interactions nonsignificant at the 20 percent level of significance; table 5). Both of these vegetative groups increased slightly on all sites during the treatment period only to subsequently decline during the stabilization period. These relationships, coupled with similar trends in botanical composition for bur-clover (fig. 11) and true clovers (fig. 12) on both the watershed and sheep/ deer pastures indicate that annual weather patterns rather than brush conversion initiated changes in botanical composition for both true and bur-clover on Watershed II. Additional support exists for this conclusion, since much of the change in botanical composition on the watershed following conversion centered around the dense sites, where bur-clover and true clovers contributed only minimally to botanical composition.

In contrast to bur-clover and true clovers, the change in botanical composition of vetches following conversion on Watershed II occurred primarily on the dense sites ( $p<0.05$; fig. 6). Moreover, vetches increased during each period of conversion on the watershed (table 6), but remained unchanged on the sheep/ deer pastures (table 7). Consequently, type conversion likely produced the increase in vetches on Watershed II, with much of this increase occurring on the newly available dense sites.

The statistically significant siteconversion interactions for Italian thistle, rattlesnake weed, geranium, and smooth cat's ear (table 5) all indicate that observed trends in botanical composition of these species following conversion on Watershed II did not occur equally on all sites.

Furthermore, all of these species displayed differing trends on the watershed and on the sheep/deer pastures, suggesting that conversion rather than annual weather patterns initiated the respective changes.

The proportion of Italian thistle in ungrazed, June vegetation on Watershed II increased throughout each period of brush conversion, but remained unchanged on the sheep/deer pastures. Since the most pronounced increase for Italian thistle occurred on the dense sites $(\mathrm{p}<0.01$; fig. 13), those sites most drastically altered by brush treatment, the invasion of Watershed II and subsequent increase of this species was probably more affected by conversion than by changing weather patterns. 


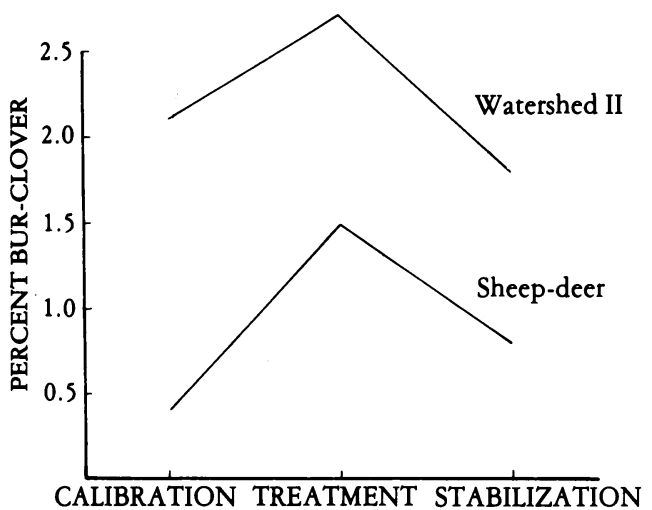

Fig. 11. Changes in proportion of bur-clover (Medicago bispida) on Watershed II and on sheep/deer pastures during brush conversion periods on Watershed II, Hopland Field Station, 1955-1973.

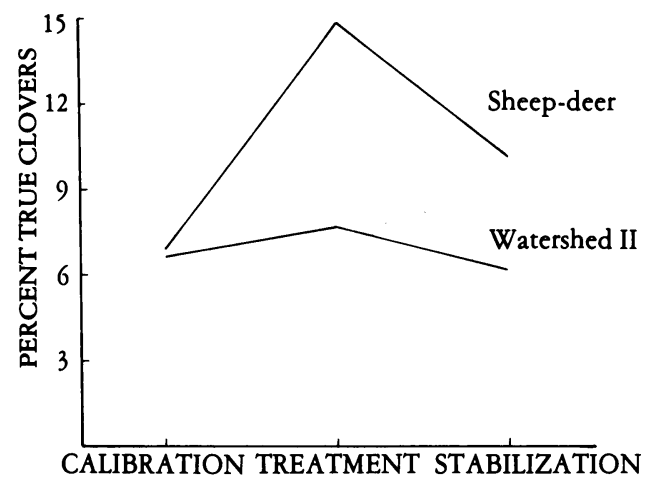

Fig. 12. Changes in proportion of true clovers (Trifolium spp.) on Watershed II and on sheep/deer pastures during brush conversion periods on Watershed II, Hopland Field Station, 1955-1973.

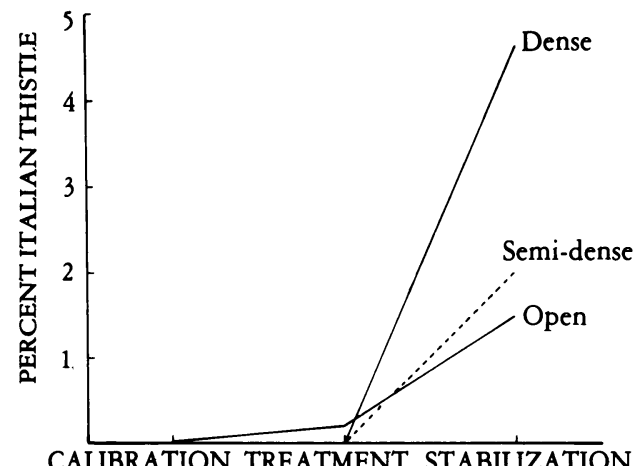

Fig. 13. Influence of three types of sites on proportion of Italian thistle (Carduus pycnocephalus) during brush conversion periods on Watershed II, Hopland Field Station, 1955 1973.
Percent botanical composition of smooth cat's ear in ungrazed June vegetation on the watershed decreased during the treatment period but remained static during the stabilization period (table 6). However, since smooth cat's ear matures early in the growing season, conclusions concerning the relative influence of conversion and annual weather patterns based solely upon June vegetation are unreliable. Figure 14 illustrates that smooth cat's ear, averaged over both the March and June sampling dates, increased on the open and semi-dense sites during the treatment period of conversion. Only minimal colonization of the dense sites by smooth cat's ear occurred. During the stabilization period, however, this species increased on the dense sites, while botanical composition on the open and semi-dense sites returned to pre-conversion levels. All three sites ultimately supported similar proportions of smooth cat's ear. Therefore, this fairly ubiquitous species was not overwhelmingly influenced by either conversion or annual weather patterns. Instead, smooth cat's ear utilizes annually available disturbed microsites and comprises a consistent portion of annual vegetation from one year to the next, particularly at mid-stages of plant succession.

Like smooth cat's ear, geranium matures early in the growing season. Figure 15 shows that geranium, averaged over both the March and June sampling dates,

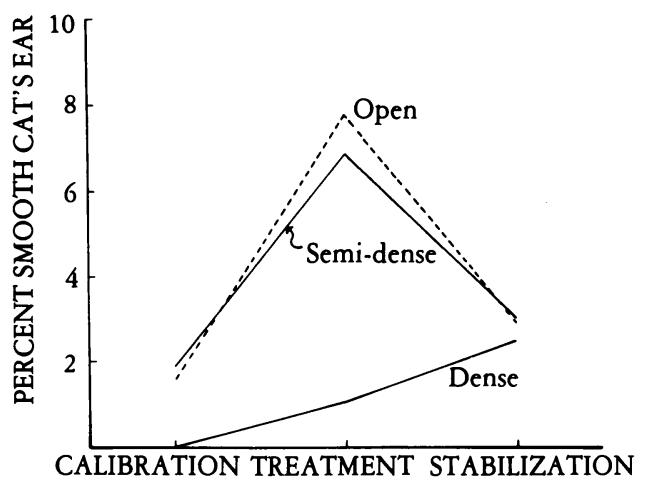

Fig. 14. Influence of three types of sites on proportion of smooth cat's ear (Hypochoeris glabra) during brush conversion periods on Watershed II, Hopland Field Station, 19551973. 


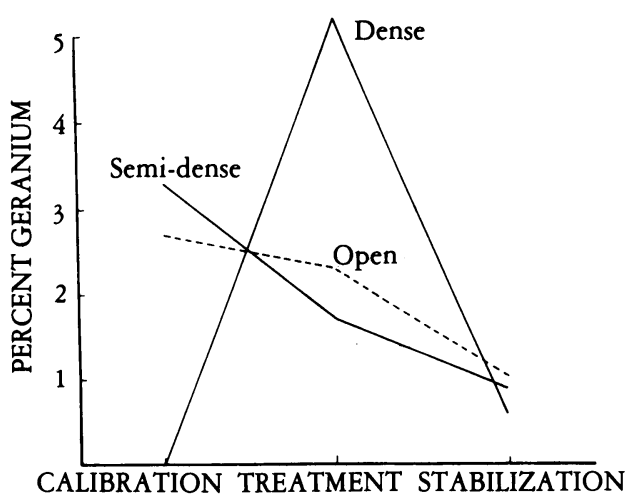

Fig. 15. Influence of three types of sites on proportion of geranium (Geranium spp.), during brush conversion periods on Watershed II, Hopland Field Station, 1955-1973.

initially colonized the dense sites following conversion, while percent botanical composition of this species declined on the open and semi-dense sites. As mulch accumulated during the stabilization period of brush conversion, the proportion of geranium declined on all three sites.

Rattlesnake weed echoed the patterns displayed by geranium following conversion on Watershed II. Initially, rattlesnake weed slightly colonized the dense sites, only to decline in botanical composition on all three sites during the stabilization period of conversion following mulch accumulation (table 4).

Although filaree also matures early in the growing season, it maintained relatively high proportions of the total vegetative cover even at the June sampling date (Pitt, 1975). Trends in botanical composition of filaree in ungrazed June vegetation differed on the watershed and sheep/deer pastures. Filaree increased on the watershed during both the treatment

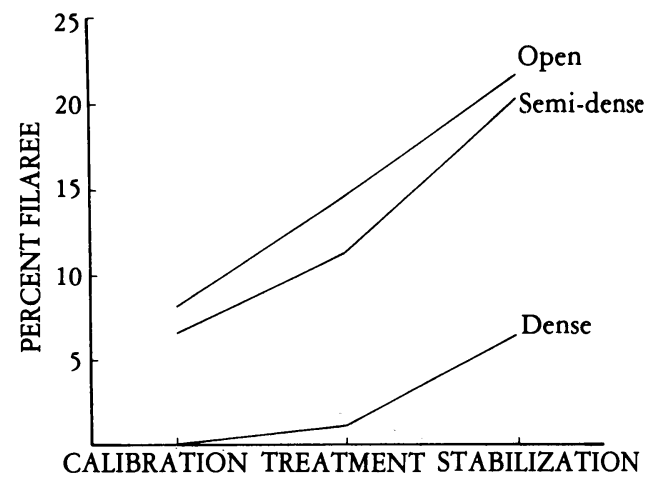

Fig. 16. Influence of three types of sites on proportion of filaree (Erodium spp.) during brush conversion periods on Watershed II, Hopland Field Station, 1955-1973.

and stabilization periods of conversion, eventually doubling from 6.0 to 15.0 percent. However, although the botanical composition of filaree increased from 12.6 to 18.6 percent on the sheep/deer pastures during the treatment period of conversion on the watershed, it eventually declined to 14.6 percent on the sheep/ deer pastures during the stabilization period of brush conversion. Apparently both conversion and annual weather patterns produced the initial increase in percent botanical composition of filaree on Watershed II, while the continued increase during the stabilization period occurred in spite of the prevailing weather patterns responsible for the decline in proportion of filaree on the sheep/deer pastures (Pitt and Heady, 1978). Filaree is capable of growing upright in tall, herbaceous vegetation, and increased on all three sites during the watershed study regardless of accumulating mulch and predominance of typically taller annual plants (fig. 16). 


\section{MANAGEMENT RECOMMENDATIONS}

A perennial problem facing ranchers in the California annual type is the wide discrepancy in available forage early in the growing season compared to late in the growing season. During the midwinter months of December, January, and February, plant growth is very slow and forage availability is consequently limited. In contrast to these midwinter months, standing crop increases dramatically during and following the rapid period of plant growth beginning approximately March 1 at the Hopland Field Station. If animal units are determined for moderate stocking rates during the midwinter months, underutilization necessarily occurs during the period of rapid plant growth. If animal units are determined for moderate stocking rates during the period of rapid plant growth and high forage availability, these animals must either be supplied supplemental feed or pastured elsewhere to avoid overgrazing and weight loss during the period of slow plant growth. Brush conversion, although increasing standing crop on Watershed II by nearly threefold, heightened this problem of seasonal stocking rates as much of the increased forage occurred between March and June, the end of the growing season. Average forage production earlier in the growing season increased only minimally above early season values before conversion. Therefore, additional animal units to utilize increased forage production following brush conversion to annual vegetation requires management flexibility in terms of alternative sources of early feed during the period of slow plant growth in midwinter. If these alternative sources of feed are not available, or if increased animal units are not anticipated, conversion to increase forage availability is not desirable.

\section{SUMMARY}

1. Changes in standing crop, cover, and percent botanical composition of annual vegetation as influenced by site and type conversion were studied from 1955 to 1973 on Watershed II at the Hopland Field Station located in Mendocino County in the central portion of the north coast mountain ranges in California. The major factors compared included three sites (characterized as open, semi-dense, and dense prior to type conversion) and three stages of brush conversion (five years before herbicidal application, six years following herbicidal application before burning of fallen woody debris, and eight years after burning of woody debris).

2. Before type conversion, herbaceous vegetation was virtually nonexistent on the dense sites and relatively scattered on the semi-dense sites. Brush conversion trebled total standing crop on the watershed, with much of this increase occurring on the formerly dense and semidense sites. However, standing crop on these dense sites remained below standing crop attained on historically grassland sites characterized as open before conversion.

3. The dense sites were located primarily on north-facing slopes of the watershed and provided relatively deep soils and amelioration of temperature and moisture extremes throughout the growing season. These characteristics of the dense sites encouraged the relative dominance of taller annual grasses, seeded perennial grasses, and forbs (wild oats, ripgut, vetches, Italian thistle), while on the open and semi-dense sites, shorter annual plants (nitgrass, silver hairgrass, rattlesnake weed, filaree, bur-clover, and true clovers) attained their greatest percent botanical composition.

4. Elimination of woody plants produced increases in percent botanical composition of those vegetative groups most able to colonize the dense sites following brush removal. These plant 
species included wild oats, perennial grasses and grasslike plants, vetches, and to a lesser degree, filaree. Alternatively, conversion produced declines in percent botanical composition of those plant species (silver hairgrass and nitgrass) not able to successfully colonize the newly available dense sites.

5. For those plant species displaying similar trends on all three sites following conversion, and/or similar trends on both Watershed II and the sheep/deer pastures, annual weather patterns may have exerted greater influences on percent botanical composition than did brush conversion. These vegetative groups included soft chess, annual fescues, bur-clover, true clovers, and filaree.

6. Brush conversion heightened the problem of seasonal stocking rates, since much of the increased forage production occurred at the end of the growing season. Adding animal units to utilize increased forage production following brush conversion to annual vegetation requires alternative sources of feed during the period of slow plant growth in midwinter.

\section{ACKNOWLEDGMENTS}

We are indebted to two groups of individuals who have been associated with this study in different ways. Planning, water and erosion measurements, livestock husbandry, wildlife observations, conversion of the vegetation, and general management of the research areas rested with the first group-and included R.H. Burgy, W.M. Longhurst, A.H. Murphy, D.T. Torell, W.C. Weir, and others associated with the Hopland Field Station. Together with the senior author, they determined experimental treatments and day-today operation for the 19 years of the study.

The second group included L. Rader, L.F. De Bano, T.E. Bedell, F. Hooper, G.D. Savelle, and M.C. Stroud, and others who were graduate students assisting in the vegetational measurements.

Contributions by all these persons made the study possible, and we are most appreciative. However, the data, analyses and ideas expressed in this paper are those of the authors and not necessarily those of others among the cooperators. 


\section{LITERATURE CITED}

BENTLEY,J.R.

1967. Conversion of chaparral areas to grassland: Techniques used in California. U.S. Dept. Agric. Handb. \#328.

BENTLEY, J. R., and M. W. TALBOT

1951. Efficient use of annual plants on cattle ranges in the California foothills. U.S. Dept. Agric. Circ. 870. BISWELL, H. H.

1956. Ecology of California grasslands. J. Range Manage. 9(1):19-24.

BURGY, R. H., and Z. G. PAPAZAFIRIOU

1974. Vegetative management and water yield relationships. Proc. 3rd Int. Semin. Hydrol. Professors. Purdue Univ., July 18-30, 1971. pp. 315-31.

DUNCAN, D. A., and R. G. WOODMANSEE

1975. Forecasting forage yield from precipitation in California's annual rangeland. J. Range Manage. 28(4):327-29.

GOWANS, K. D.

1958. Soil survey of the Hopland Field Station. Calif. Agric. Exp. Sta.

HEADY, H. F.

1956. Evaluation and measurement of the California annual type. J. Range Manage. 9(1):25-27.

1957. Effect of cages on yield and composition in the California annual type. J. Range Manage. 10(4):175-77.

1958. Vegetational changes in the California annual type. Ecology 39(3):402-15.

1961. Continuous vs. specialized grazing systems: $A$ review and application to the California annual type. J. Range Manage. 14(4):182-93.

HOOPER, J. F., and H. F. HEADY

1970. An economic analysis of optimum rates of grazing in the California annual-type grassland. J. Range Manage. 23(5):307-11.

HORMAY, A. L.

1944. Moderate grazing pays on California annual-type ranges. U.S. Dept. Agric. Leaf. 239.

JONES, M. B., and R. A. EVANS

1960. Botanical composition changes in annual grassland as affected by fertilization and grazing. Agron. J. 52(8):459-61.

McNAUGHTON, S. J.

1968. Structure and function in California grasslands. Ecology 49(5):962-72.

MURPHY, A. H.

1970. Predicted forage yield based on fall precipitation in California annual grasslands. J. Range Manage.

NAVEH, $Z$. 23(5):363-65.

1967. Mediterranean ecosystems and vegetation types in California and Israel. Ecology 48(3):445-59. PITT, M. D.

1975. The effects of site, season, weather patterns, grazing, and brush conversion on annual vegetation, Watershed II, Hopland Field Station. Univ. Calif. Ph.D. diss. 281 pp.

PITT, M. D., and H. F. HEADY

1978. Response of annual vegetation to temperature and rainfall patterns in northern California. Ecology 59(2):336-50.

TALBOT, M. W., and H. H. BISWELL

1942. The forage crop and its management. Univ. Calif. Agric. Exp. Sta., Bull. 633:13-49.

TALBOT, M. W., H. H. BISWELL, and A. L. HORMAY

1939. Fluctuations in the annual vegetation of California. Ecology 20(3):394-402. 
